\title{
The thioredoxin reductase system of mycoplasmas
}

\author{
G. Ben-Menachem, ${ }^{1}$ R. Himmelreich, ${ }^{2}$ R. Herrmann, ${ }^{2}$ Y. Aharonowitz ${ }^{3}$ \\ and S. Rottem ${ }^{1}$
}

Author for correspondence: S. Rottem. Tel: +972 2675 8148. Fax: +972 26784010.

e-mail: rottem@cc.huji.ac.il

\footnotetext{
1 Department of Membrane and Ultrastructure Research, The Hebrew University-Hadassah Medical School, POB 12272, Jerusalem 91120, Israel

2 Department of Microbiology, University of Heidelberg, Im Neuenheimer Feld 282 D-6900 Heidelberg, Germany

3 Department of Molecular Microbiology and Biotechnology, The George S. Wise Faculty of Life Sciences, Tel Aviv University, Ramat Aviv 69978, Israel
}

\begin{abstract}
Representative species of the Mollicutes possess a thioredoxin reductase system (NTS) composed of a low-molecular-mass thioredoxin (TRX) and NADPH-binding thioredoxin reductase (NTR). The TRXs of Mycoplasma pneumoniae and $M$. capricolum have molecular masses of 11.2 and $12 \mathrm{kDa}$, respectively, and are stable at $90^{\circ} \mathrm{C}$ for $10 \mathrm{~min}$. Both TRXs reacted with monospecific polyclonal antibodies generated against the Bacillus subtilis TRX, but not with anti-Escherichia coli TRX antisera. The $M$. capricolum and $M$. pneumoniae NTRs were partially purified and were found to be active with the homologous TRX, but not with the TRX of B. subtilis or E. coli. The NTS activity had an optimal pH of 6.5-7.5 and was dependent on NADPH as an electron donor, a requirement which could not be fulfilled by NADH. The genes encoding the TRX and NTR (trXA and trXB) of M. pneumoniae were cloned and sequenced. The comparative analysis of the predicted amino acid sequence of trxA showed that the $11.2 \mathrm{kDa}$ protein (102 aa) shared $26-68 \%$ sequence similarity with products of other known trxA genes and contained the conserved active site Cys-Gly-Pro-Cys. The predicted amino acid sequence of trxB contained 315 residues with a conserved NADPH binding domain and FAD binding domains I and II. The cysteine dithiol redox active region had isoleucine rather than threonine at the active site, as compared with other NTRs. The high activity of the NTS in mycoplasmas suggests that mycoplasmas may have evolved the NTS to protect themselves from the consequences of their self-generated oxidative challenge.
\end{abstract}

Keywords: thioredoxin, NADP-thioredoxin reductase, Mycoplasma capricolum, Mycoplasma pneumoniae, Mollicutes

\section{INTRODUCTION}

Thioredoxins (TRXs) are widely distributed in eukaryotic cells and are also found in prokaryotes (Gleason \& Holmgren, 1988; Buchanan et al., 1994). In the $\mathrm{NADP}^{+} /$ thioredoxin system (NTS), the low-molecular-mass TRX proteins undergo reversible reduction which is linked to NADPH via a flavin enzyme, NADPH-thioredoxin reductase (NTR; Gleason \& Holmgren, 1988). TRX and NTR catalyse the transfer of electrons from $\mathrm{NADPH}$ to disulfides in proteins and low-molecular-

Abbreviations: DTNB, 5,5'-dithio-bis(1-nitrobenzoic acid); mBBr, monobromobimane; NTR, NADPH-thioredoxin reductase; NTS, NADP'-thioredoxin reductase system; TRX, thioredoxin.

The GenBank accession numbers for the nucleotide sequences reported in this paper are U51987 (trXA) and U51988 (trxB). mass compounds. TRX contains a pair of vicinal redox-active cysteine thiols (-CGPC-) that undergo reversible oxidation to form a disulfide bridge. Oxidized TRX is reduced by NTR which possesses a similar dithiol redox active site. In Escherichia coli, NTR is a dimeric protein with two identical subunits (Luthman $\&$ Holmgren, 1982); the flavin moiety (FAD) mediates transfer of electrons from NADPH to the redox-active site. Evidence from a previous study suggests that the NADP-thioredoxin system occupies a central position in controlling the division and proliferation of prokaryotes (Gleason \& Holmgren, 1988). Principal sites of TRX action in eukaryotes lie at the levels of transcription (Matthews et al., 1992; Schenk et al., 1994), DNA replication (Buchanan et al., 1994) and hormone action (Holmgren, 1979a). In addition to its regulatory activity, current evidence suggests that the NTS plays a role in 
correcting the effects of oxidative stress on proteins, maintaining them in their active state (Fernando et al., 1992; Derman et al., 1993) and may be involved in protein folding through the proper organization of disulfide bonds during the folding process (Pigiet \& Schuster, 1986). While there is a wealth of information on the NTS in eukaryotes, much less is known about prokaryotes, where most studies have been performed with E. coli (Gleason \& Holmgren, 1988) and with Streptomyces clavuligerus (Cohen et al., 1993, 1994; Aharonowitz et al., 1993).

Mycoplasmas (class Mollicutes) are the smallest and simplest self-replicating prokaryotes. They are widely distributed in nature as parasites and pathogens of man and other animals, insects and plants. The fact that mycoplasmas have the smallest genome of any living organism, are devoid of a rigid cell wall and are bound by a single membrane has made them attractive and useful tools for investigating basic problems in biology. The present study was prompted by the finding that the activity of a key $55 \mathrm{kDa}$ phosphoprotein kinase present in a variety of mycoplasmas is very sensitive to the redox state of its cysteine residues $(Z$. Borovsky \& S. Rottem, unpublished data) and activity can be detected only in the presence of excess thiol reagents. While looking for an enzyme system that would replace the need for thiol reagents, an NTS was detected and is thus implicated in keeping cysteines of mycoplasmal proteins in the reduced state. The aim of this study was to describe and characterize the NTS in two representative mycoplasmas, $M$. capricolum, a fast growing mycoplasma widely used in physiological studies and $M$. pneumoniae, a well-established human pathogen.

\section{METHODS}

Growth conditions and the isolation of cell fractions. $M$ pneumoniae (M129), M. fermentans and M. penetrans were grown in a modified Channock medium (Razin \& Rottem, 1976) supplemented with $20 \%(\mathrm{v} / \mathrm{v})$ inactivated horse serum (56 ${ }^{\circ} \mathrm{C}$ for $30 \mathrm{~min}$ ). M. capricolum, M. gallisepticum (A5969) and Acholeplasma laidlawii were grown in a modified Edward medium (Razin \& Rottem, 1976) supplemented with $4 \%$ $(\mathrm{v} / \mathrm{v})$ inactivated horse serum. Spiroplasma melliferum and Sp. floricola were grown in a modified Saglio medium (Shirazi et al., 1995). The cultures were inoculated with a frozen inoculum at a level of $1-5 \%$ and then grown without aeration for 24-48 h. The Mycoplasma and Acholeplasma species were grown at $37^{\circ} \mathrm{C}$ whereas the Spiroplasma species were grown at $32{ }^{\circ} \mathrm{C}$. Growth was monitored by measuring the $\mathrm{OD}_{640}$ of the culture and by recording $\mathrm{pH}$ changes in the growth medium. Cells were harvested by centrifugation at $12000 \mathrm{~g}$ for $15 \mathrm{~min}$. The cells were washed twice in $0.25 \mathrm{M} \mathrm{NaCl}$ containing $10 \mathrm{mM}$ Tris $/ \mathrm{HCl}(\mathrm{pH} 7.5)$ and incubated in the $\mathrm{NaCl} /$ Tris solution containing $15 \mathrm{mg}$ digitonin $\mathrm{ml}^{-1}$ for $15 \mathrm{~min}$ at $37^{\circ} \mathrm{C}$. The cells were then disrupted by ultrasonic treatment for 2-5 min in a W-350 Heat System Sonifier operated at $50 \%$ duty cycles at $160 \mathrm{~W}$. Membranes were separated from the soluble fraction by centrifugation at $37000 \mathrm{~g}$ for $30 \mathrm{~min}$. The supernatant was stored at $-70^{\circ} \mathrm{C}$ until used.

Purification of NTR and TRX. NTR and TRX were first fractionated by ammonium sulfate precipitation. Protein fractions sedimented at $50-80 \%$ ammonium sulfate saturation ( $1 \mathrm{ml}$ containing $5 \mathrm{mg}$ protein $\mathrm{ml}^{-1}$ ) were further purified by affinity chromatography on a blue Sepharose (Sigma) column $(5 \times 20 \mathrm{~mm})$ prewashed with $10 \mathrm{ml} 10 \mathrm{mM}$ sodium phosphate buffer $(\mathrm{pH} 7 \cdot 5)$. The column was eluted by a stepwise gradient of $0-1 \mathrm{M} \mathrm{NaCl}$ in sodium phosphate buffer and excess salts were removed by dialysis $\left(2 \mathrm{~h}\right.$ at $4{ }^{\circ} \mathrm{C}$ against sodium phosphate buffer).

Enriched TRX preparations of $M$. capricolum and $M$. pneumoniae were obtained by heating the $50-80 \%$ ammonium sulfate fraction to $80^{\circ} \mathrm{C}$ for $15 \mathrm{~min}$. TRX-enriched preparations of Bacillus subtilis or E. coli were obtained by heating the total soluble fraction to $80^{\circ} \mathrm{C}$ for $15 \mathrm{~min}$. The heated preparations were centrifuged at $37000 \mathrm{~g}$ for $10 \mathrm{~min}$, and the TRX-enriched supernatant was separated from the sediment containing denatured proteins.

NTS activity. NTS activity was assayed using 5,5'-dithio-bis(1nitrobenzoic acid) (DTNB; Holmgren, 1977). The reaction mixtures, in wells of an ELISA microplate, contained (in a total volume of $200 \mu \mathrm{l}) 50 \mathrm{mM}$ Tris $/ \mathrm{HCl}(\mathrm{pH} 8.0), 1 \mathrm{mM}$ EDTA, $0.02 \mathrm{mM}$ DTNB $(5 \mu \mathrm{l}$ of an ethanolic solution of $4 \mathrm{mg}$ DTNB $\left.\mathrm{ml}^{-1}\right), 10 \mu$ of a TRX-enriched preparation $(10-20 \mu \mathrm{g})$ and $10 \mu \mathrm{l}$ of the partially purified NTR $(5-50 \mu \mathrm{g})$. The reaction was started by the addition of $0.2 \mathrm{mM}$ NADPH and activity was determined at $37^{\circ} \mathrm{C}$ by measuring the increase in $A_{405}$ $\left(\Delta A_{405}\right)$ during the initial reaction period (2-5 min) using an ELISA plate reader and expressed as $\Delta A_{405} \min ^{-1}$ (units) or as $\triangle A_{405} \min ^{-1}$ (mg protein) ${ }^{-1}$ (sp. act. units).

NTS activity was also assayed by following the reduction of insulin disulfides in the presence of NADPH (Holmgren, $1979 \mathrm{~b}$ ). Reaction mixtures (in a total volume of $120 \mu \mathrm{l}$ ) contained $260 \mathrm{mM}$ HEPES buffer ( $\mathrm{pH} 7.6$ ), $10 \mathrm{mM}$ EDTA, $2 \mathrm{mM}$ NADPH, $1 \mathrm{mM}$ bovine insulin and preparations containing TRX and NTR. The reaction mixtures were incubated at $37^{\circ} \mathrm{C}$ and stopped by the addition of $0.5 \mathrm{ml}$ of a solution containing $2 \mathrm{mg} \mathrm{DTNB}$ and $6 \mathrm{M}$ guanidine. $\mathrm{HCl}(\mathrm{pH} 8 \cdot 0)$. The reduction resulted in the precipitation of the $\beta$-chains and thus turbidity in the reaction mixture. Activity was determined spectrophotometrically.

Analytical methods. Protein in the cell fractions was determined by the method of Bradford (1976). Labelling cell proteins by monobromobimane $(\mathrm{mBBr})$ was performed by a modification of a procedure described by Wong et al. (1995). In brief, $20 \mu 12.0 \mathrm{mM} \mathrm{mBBr}$ in $100 \mathrm{mM}$ Tris $/ \mathrm{HCl}$ (pH 7.9) was added to $175 \mu \mathrm{l} \mathrm{M}$. capricolum cell suspensions (containing $5 \mathrm{mg}$ cell protein $\mathrm{ml}^{-1}$ ) harvested at the various phases of growth and incubated at room temperature for $15 \mathrm{~min}$. The cells were then solubilized by the addition of $200 \mu \mathrm{l} 2 \%$ SDS in $10 \%$ glycerol containing $0.001 \%$ bromophenol blue and analysed by SDS-PAGE (Laemmli, 1970). The gels $(16 \%$, $1.5 \mathrm{~mm}$ thick) were developed for $16 \mathrm{~h}$ at a constant current of $9 \mathrm{~mA}$. The gels were then placed in $12 \%(\mathrm{w} / \mathrm{v})$ trichloroacetic acid and soaked for $4-6 \mathrm{~h}$ with one change of solution to fix the proteins; gels were then transferred to a solution of $40 \%$ methanol $/ 10 \%$ acetic acid for $8-10 \mathrm{~h}$ to remove excess $\mathrm{mBBr}$ and visualized under UV light $(365 \mathrm{~nm})$.

For immunoblotting, the SDS-PAGE gels were washed three times for $10 \mathrm{~min}$ in distilled water and proteins were transferred to nitrocellulose paper (Wong et al., 1995). The blot was then blocked by soaking twice for $30 \mathrm{~min}$ in $200 \mathrm{ml}$ of a buffer consisting of $20 \mathrm{mM}$ Tris $/ \mathrm{HCl}(\mathrm{pH} \mathrm{7.5}$ ) and $0.15 \mathrm{M}$ $\mathrm{NaCl}$ (TBS buffer) containing $5 \%$ non-fat dried milk. The blocked blot was incubated for $4 \mathrm{~h}$ with a 1:500 dilution of rabbit antiserum generated against $E$. coli and $B$. subtilis TRX 
in $5 \%$ non-fat dried milk in TBS buffer and then washed twice for $15 \mathrm{~min}$ with TBS buffer. Goat anti-rabbit IgG (alkaline phosphatase conjugate, Bio-Rad) was utilized to probe the blots. The alkaline phosphatase conjugate was diluted 1:3000 with $5 \%$ non-fat milk in TBS buffer and incubated with the blots for $1 \mathrm{~h}$. The blots were then washed twice in TBS buffer and developed with the BCIP/NBT colour development solution (Bio-Rad).

Identification of genes and cloning. M. pneumoniae M129 was the source of genomic DNA used for amplification by PCR. Unless otherwise stated a cosmid library (Wenzel \& Herrmann, 1989) comprising the complete genome of $M$. pneumoniae M129 was used for subcloning of genes and Southern blot analysis of $M$. pneumoniae DNA. The cosmids of the ordered M. pneumoniae gene library were individually digested with $E c o$ RI. The fragments were separated by agarose gel electrophoresis and analysed using standard protocols for Southern blotting (Sambrook et al., 1989). Sets of degenerate oligonucleotides derived from conserved regions were used as $\operatorname{tr} x A$ and $\operatorname{tr} x B$ gene-specific probes. Fragments which gave a positive signal under the most stringent hybridization conditions were subcloned from the corresponding cosmid in the plasmid vector $\mathrm{pBC}$ (Stratagene). As an alternative to subcloning from cosmid DNA, regions of interest were amplified by PCR from genomic M. pneumoniae DNA and then cloned either in the plasmid pBC or bacteriophage M13 DNA.

Oligonucleotides. The oligonucleotides were synthesized using phosphoramidite chemistry with a solid carrier on a model 364 DNA/RNA synthesizer from Applied Biosystems (Caruthers, 1982; Ferretti et al., 1986). The oligonucleotides o.THR1 [5' GA(CT)TT(CT)TG(GA)GC(ACG)GA(GA)TG(GA)TG], o.THR2 [5' GA(CT)TT(CT)TG(GA)GC(TA)GA(GA)G(GA)TG], o.THRSE1 [5' TG(CT)GC(CG)AC(AGGT) TG(CT)GA(CT)CG] and o. THRSE2 [5' TG(CT)GC(TA)$\mathrm{AC}(\mathrm{AGCT}) \mathrm{TG}(\mathrm{CT}) \mathrm{GA}(\mathrm{CT}) \mathrm{GG}]$ are $\operatorname{tr} x A$ and $\operatorname{tr} x B$ genespecific probes. 0.3605 (5' GCAACAATGCGAAACTCCTGA) and 0.4257 (5' GGTTATCCTGGTTTTCGGGTCAC) were used for amplification of the $\operatorname{tr} x B$ gene.

Long range PCR. The improved PCR method for the amplification of DNA fragments up to $45 \mathrm{kbp}$ was used (Cheng et al., 1994). The reactions were performed with the Gene Amp XLPCR kit (Perkin-Elmer) according to the manufacturer's protocol. Genomic M. pneumoniae DNA used for amplification was purified as described previously (Wenzel \& Herrmann, 1988). The PCR products were purified by agarose gel electrophoresis on $0.5-1 \%$ agarose gels.

Hybridization with oligonucleotides. Nylon filters were preincubated for at least $4 \mathrm{~h}$ at $37^{\circ} \mathrm{C}$ in a mixture containing $5 \times$ SSC $(1 \times$ SSC is $150 \mathrm{mM} \mathrm{NaCl}$ in $15 \mathrm{mM}$ sodium citrate, $\mathrm{pH} 7 \cdot 2), 10 \times$ Denhardt's solution ( $1 \times$ Denhardt's solution is $0.02 \%$ Ficoll, $0.02 \%$ polyvinylpyrrolidone and $0.02 \%$ bovine serum albumin), $0.05 \%$ SDS and $100 \mu \mathrm{g}$ denatured herring sperm DNA $\mathrm{ml}^{-1}$. For hybridization, the labelled preheated $\left(65^{\circ} \mathrm{C}\right.$ for $5 \mathrm{~min}$ ) probe was mixed with the same buffer as used for prehybridization and adjusted to $5 \times 10^{5} \mathrm{c}$.p.m. $\mathrm{ml}^{-1}$ $(0 \cdot 1-0 \cdot 5 \mathrm{pmol})$. Filters were hybridized overnight at $37^{\circ} \mathrm{C}$. Depending on the length and $\mathrm{G}+\mathrm{C}$ content of the oligonucleotide between 0 and $25 \%$ formamide was added to the hybridization solution to optimize the conditions. The melting temperatures for the oligonucleotides with the highest and lowest $G+C$ content were estimated and these values used for calculation of the formamide concentration in the hybridization mixture (Wenzel \& Herrmann, 1988). After hybridization, the filters were washed twice for $20 \mathrm{~min}$ with $5 \times$ SSC at $37^{\circ} \mathrm{C}$ and $0.05 \%$ SDS, dried and autoradiographed.
DNA sequencing and computer-assisted analysis. The sequence data in this study were generated by the enzymic dideoxy chain-termination method described by Sanger et al. (1977). The radioactive label was substituted by a fluorescent label and Taq polymerase was used in the reaction (Ansorge et al., 1987). Computer analyses were done with the program package HUSAR (Heidelberg Unix Sequence Analysis Resources) release 4.0 at the German Cancer Research Centre, Heidelberg, Germany. This package is based on the GCG program package version Unix-8.01 of the Genetics Computer Group, Wisconsin. Multiple alignment was performed with the program package LASERGENE (Dnastar). Percentage divergence was calculated by comparing sequence pairs in relation to the phylogeny reconstructed by the program MEGALIGN (Dnastar). The similarity index compares sequences directly, without accounting for phylogenetic relationships.

\section{RESULTS AND DISCUSSION}

\section{NTS activity in Mollicutes}

The NTS activity of nine mollicutes was tested by following the reduction of DTNB in the presence of NADPH. High activities (0.09-0.25 sp. act. units) were found in the Mycoplasma species M. capricolum (kid), M. pneumoniae (M129), M. gallisepticum (A5969), M. fermentans and $M$. penetrans, whereas the activities found in A. laidlawii, Sp. melliferum and Sp. floricola were low $(0.008-0.035 \mathrm{sp}$. act. units $\rangle$. All subsequent experiments were performed with $M$. capricolum and M. pneumoniae. HPLC analysis of $\mathrm{mBBr}$ derivatives of low-molecular-mass thiols obtained from $M$. capricolum and $M$. pneumoniae extracts revealed that these organisms lack glutathione, but contain substantial levels of another unidentified thiol metabolite (R. C. Fahey \& S. Rottem, unpublished data). Furthermore, these organisms lack glutathione reductase (BenMenachem et al., 1994), suggesting that the thiol metabolites are maintained in their reduced form mainly through the NTS.

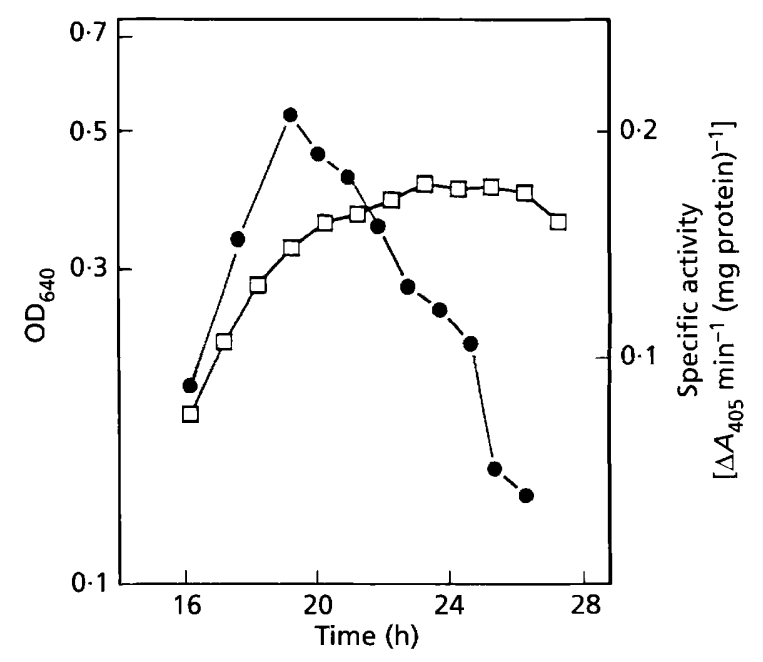

Fig. 1. The effect of culture age on NTS activity. $\square, \mathrm{OD}_{640} ;$ specific activity. 


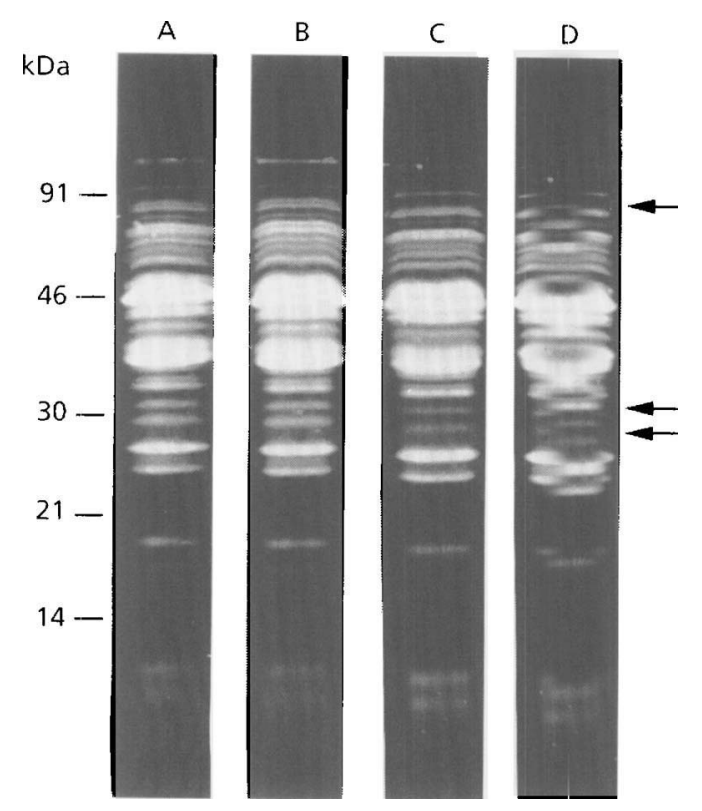

Fig. 2. Changes in fluorescence intensities of $M$. capricolum proteins upon ageing. $M$. capricolum cells were harvested at various times and labelled by the SDS-PAGE/mBBr procedure (Wong et al, 1995). Lanes: $A, 18 \mathrm{~h}, \mathrm{OD}_{640} 0.25 ; \mathrm{B}, 22 \mathrm{~h}$, $\mathrm{OD}_{640} 0.40 ; \mathrm{C}, 26 \mathrm{~h}, \mathrm{OD}_{640} 0.42 ; \mathrm{D}, 32 \mathrm{~h}, \mathrm{OD}_{640} 0.30$. Arrows point to bands with decreased labelling intensities.

\section{NTS activity and the redox state of proteins during growth}

Fig. 1 shows the results of a representative experiment on the changes in NTS activity of M. capricolum cells during growth. Highest activity was found in cells harvested at the mid-exponential phase of growth, whereas at the stationary phase of growth, the activity was very low. Hence, mid-exponential phase cells were utilized throughout this study. Using the in vivo $\mathrm{mBBr}$ labelling technique, we obtained evidence for a change in the redox state of several M. capricolum cell proteins upon ageing. When intact cells, harvested at different phases of growth, were labelled with $\mathrm{mBBr}$ immediately after harvest the major change observed was a progressive decrease in $\mathrm{mBBr}$ binding to a $29 \mathrm{kDa}$ and a $31 \mathrm{kDa}$ protein upon ageing of the culture (Fig. 2). The relative amounts of the $29 \mathrm{kDa}$ and $31 \mathrm{kDa}$ proteins in stationary-phase cells and early-exponential-phase cells were apparently the same as suggested by the intensity of the Coomassie-blue-stained bands observed after SDS-PAGE analysis (data not shown). Therefore, it is suggested that the decrease in the redox state of these proteins upon ageing may be due to a decrease in the NTS activity (see Fig. 1).

The NTS was further analysed by following the reduction of the S-S bonds joining the $\alpha$ and $\beta$ insulin chains (Holmgren, 1979b). The extent and kinetics of the insulin reduction in various cell preparations was similar to that obtained with the DTNB reduction assay

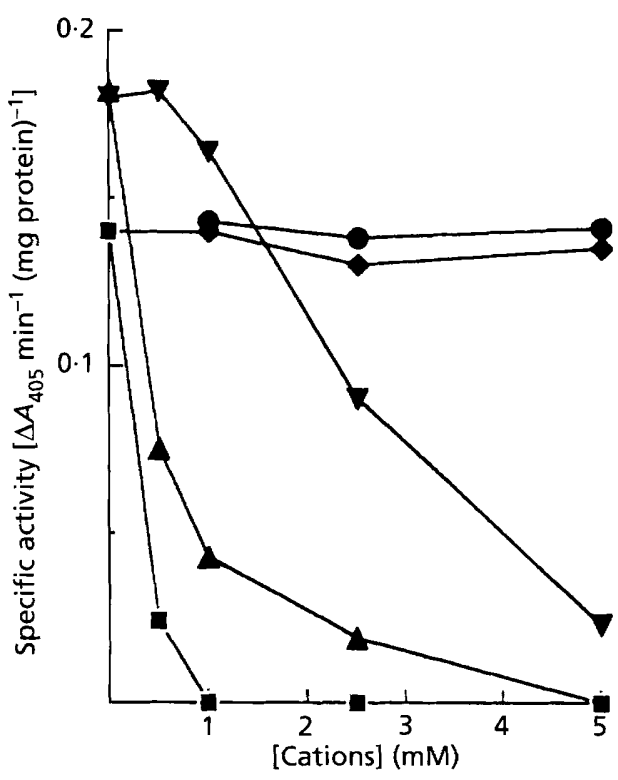

Fig. 3. The effect of divalent cations on $M$. capricolum NTS activity. O, $\mathrm{Mg}^{2+} ; \bullet, \mathrm{Ca}^{2+} ; \nabla, \mathrm{Zn}^{2+} ; \mathbf{\Delta}, \mathrm{Fe}^{2+} ; \mathbf{\square}, \mathrm{Cu}^{2+}$. All divalent cations were added as chlorides. The results presented are the means of three experiments done with different batches of cells.

(data not shown). The NTS activity was confined to the soluble fraction of the cells and was dependent on $\mathrm{NADPH}$ as an electron donor, a requirement which could not be fulfilled by NADH (data not shown). The optimal $\mathrm{pH}$ for activity was $6 \cdot 5-7 \cdot 5$. Fig. 3 shows the effect of various cations on M. capricolum NTS activity. Whereas $\mathrm{Ca}^{2+}$ and $\mathrm{Mg}^{2+}$ had very little effect, $\mathrm{Mn}^{2+}$ (data not shown), $\mathrm{Zn}^{2+}, \mathrm{Cu}^{2+}$ and $\mathrm{Fe}^{2+}$ at concentrations of $1-4 \mathrm{mM}$ inhibited the activity. NTS activity was markedly stimulated by high concentrations of monovalent cations, with highest activities observed at concentrations of $\mathrm{Na}^{+}, \mathrm{K}^{+}$or $\mathrm{NH}_{4}^{+}$greater than $150 \mathrm{mM}$ (data not shown).

\section{The partial purification of NTR and TRX}

Partial purification of $M$. capricolum NTR was obtained by ammonium sulfate precipitation followed by affinity chromatography using a blue Sepharose column (Table $1)$. Very similar results were obtained with the $M$. pneumoniae NTR. The blue Sepharose step separated the TRX from the NTR. The TRX was exclusively eluted in the void volume whereas the NTR was eluted by $100 \mathrm{mM} \mathrm{NaCl}$ in $10 \mathrm{mM}$ sodium phosphate buffer ( $\mathrm{pH} 7 \cdot 5)$. Therefore, the NTR-enriched blue Sepharose fractions did not show NTS activity unless an enriched TRX preparation, obtained by heating the $50-80 \%$ ammonium sulfate fraction to $80^{\circ} \mathrm{C}$ for $15 \mathrm{~min}$ was added to the reaction mixture. The yield of activity at this stage was $80-85 \%$ and a purification of about 30 fold was obtained (Table 1 ). The partially purified $M$. capricolum and M. pneumoniae NTRs were active with 
Table 1. Partial purification of the NTR of $M$. capricolum NTS

NTS activity was measured in reaction mixtures containing 5-20 $\mu$ g protein of the various preparations.

\begin{tabular}{|lccccc|}
\hline Preparation & $\begin{array}{c}\text { Protein } \\
(\mathbf{m g})\end{array}$ & $\begin{array}{c}\text { Total activity } \\
(\text { units })\end{array}$ & $\begin{array}{c}\text { Yield } \\
(\%)\end{array}$ & $\begin{array}{c}\text { Specific activity } \\
{[\text { units }} \\
\left.\text { (mg protein })^{-1}\right]\end{array}$ & $\begin{array}{c}\text { Purification } \\
\text { (-fold })\end{array}$ \\
\hline Crude soluble fraction & $32 \cdot 40$ & $7 \cdot 09$ & $100 \cdot 0$ & $0 \cdot 22$ & 0 \\
$50-80 \%$ Ammonium sulfate fraction & $6 \cdot 75$ & $9 \cdot 48$ & $133 \cdot 0$ & $1 \cdot 40$ & $6 \cdot 4$ \\
Blue Sepharose column* & $1 \cdot 00$ & $6 \cdot 00$ & $84 \cdot 5$ & $6 \cdot 00$ \\
\hline
\end{tabular}

*Activity was measured in the presence of an enriched M. capricolum TRX preparation (10 $\mu \mathrm{g}$ protein).

(a)

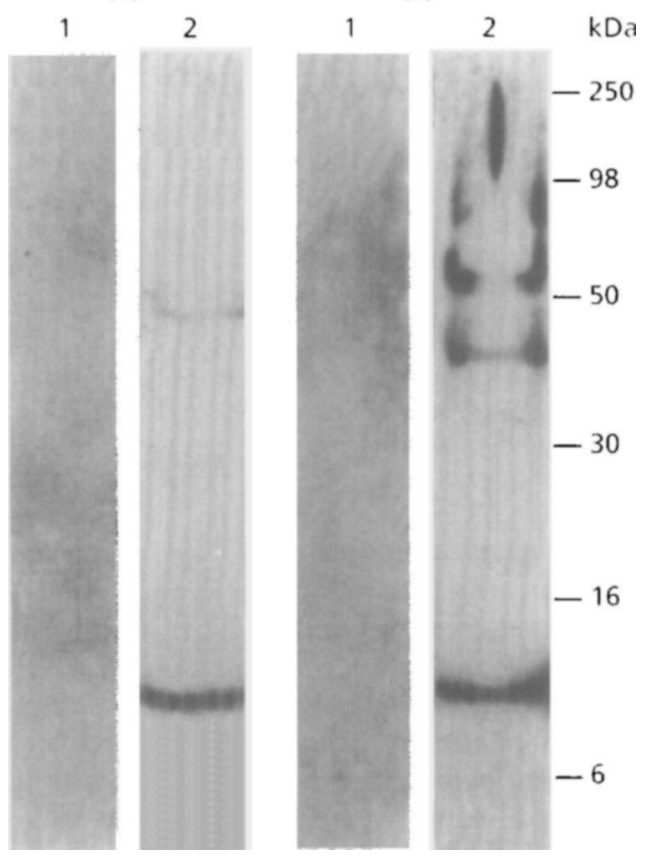

Fig. 4. Antigenic cross-reactivity of $M$. capricolum and $M$. pneumoniae TRX preparations with E. coli and B. subtilis TRX. Partially purified TRX preparations from $M$. capricolum (a) and $M$. pneumoniae (b) were separated on a $10-20 \%$ SDSpolyacrylamide gel, transferred to nitrocellulose and immunoblotted with either rabbit anti-E. coli TRX antibodies (1) or rabbit anti-B. subtilis TRX antibodies (2).

homologous TRX preparations, but almost no activity was obtained with the TRX of E. coli or B. subtilis (data not shown).

SDS-PAGE analyses of partially purified TRX preparations on a $10-20 \%$ acrylamide gel in the presence of $0 \cdot 1 \mathrm{M}$ tricine revealed one major band with an apparent molecular mass of $12 \mathrm{kDa}$ in $M$. capricolum and three bands with apparent molecular masses of $10,11.5$ and $14 \mathrm{kDa}$, respectively, in $M$. pneumoniae. N-terminal analysis of the $M$. capricolum $12 \mathrm{kDa}$ band revealed an amino acid sequence of ADIIKIXSKEQFDKE, in complete agreement with the deduced amino acid sequence of the M. capricolum trxA gene (Bork et al., 1995). When the partially purified TRX preparations, separated by SDS-PAGE, were blotted onto nitrocellulose and probed with polyclonal antisera raised against $E$. coli and B. subtilis TRX, the antisera against B. subtilis reacted strongly with the $12 \mathrm{kDa}$ protein in $M$. capricolum and with the $11.5 \mathrm{kD}$ a protein in M. pneumoniae. No reaction was observed with antisera against $E$. coli TRX (Fig. 4).

\section{Cloning and nucleotide sequence of the $\operatorname{tr} x A$ gene}

Southern blot analysis of the EcoRI-digested cosmid gene bank of $M$. pneumoniae with oligonucleotides o.THR 1 and o.THR2 detected a $6.7 \mathrm{kbp}$ EcoRI fragment. This fragment was present in the overlapping cosmids pcosMPK8 and pcosMPA65. After subcloning into the plasmid $\mathrm{pBC}$ the entire $6.7 \mathrm{kbp}$ DNA fragment was sequenced.

The nucleotide sequence contained an ORF predicting a protein of 102 aa which shared significant homologies with TRXs from other species (Fig. 5). In particular, the characteristic cysteine dithiol redox-active region (-CGPC-) was conserved. The active segment in the M. pneumoniae TRX is located at positions $30-33$. The calculated molecular mass for the translation product of the $\operatorname{tr} x A$ gene was $11215 \mathrm{Da}$. This was in good agreement with the molecular mass of TRXs of other species and with the results obtained by immunoblot analysis (Fig. 4). The sequence analysis of the regions flanking the $\operatorname{tr} x A$ gene did not detect an ORF encoding a $\operatorname{tr} x B$ gene, indicating that, unlike in Strep. clavuligerus (Cohen et al., 1993), the $\operatorname{tr} x B$ and $\operatorname{tr} x A$ genes are not organized in an operon. This resembled the organization of E. coli (Lim et al., 1985), Haemophilus influenzae (Fleischmann et al., 1995) and M. genitalium (Fraser et al., 1995).

The multiple protein sequence alignment of $M$. pneumoniae TRX with some other known TRXs revealed similarity of $26-68 \%$ (Fig. 5). The highest score was obtained with $M$. genitalium. Despite the almost identical degree of similarity between $M$. pneumoniae TRX and the TRXs of B. subtilis and E. coli (34 and 31\% respectively), antisera raised against $B$. subtilis TRX bound to M. pneumoniae TRX, whereas antisera raised 

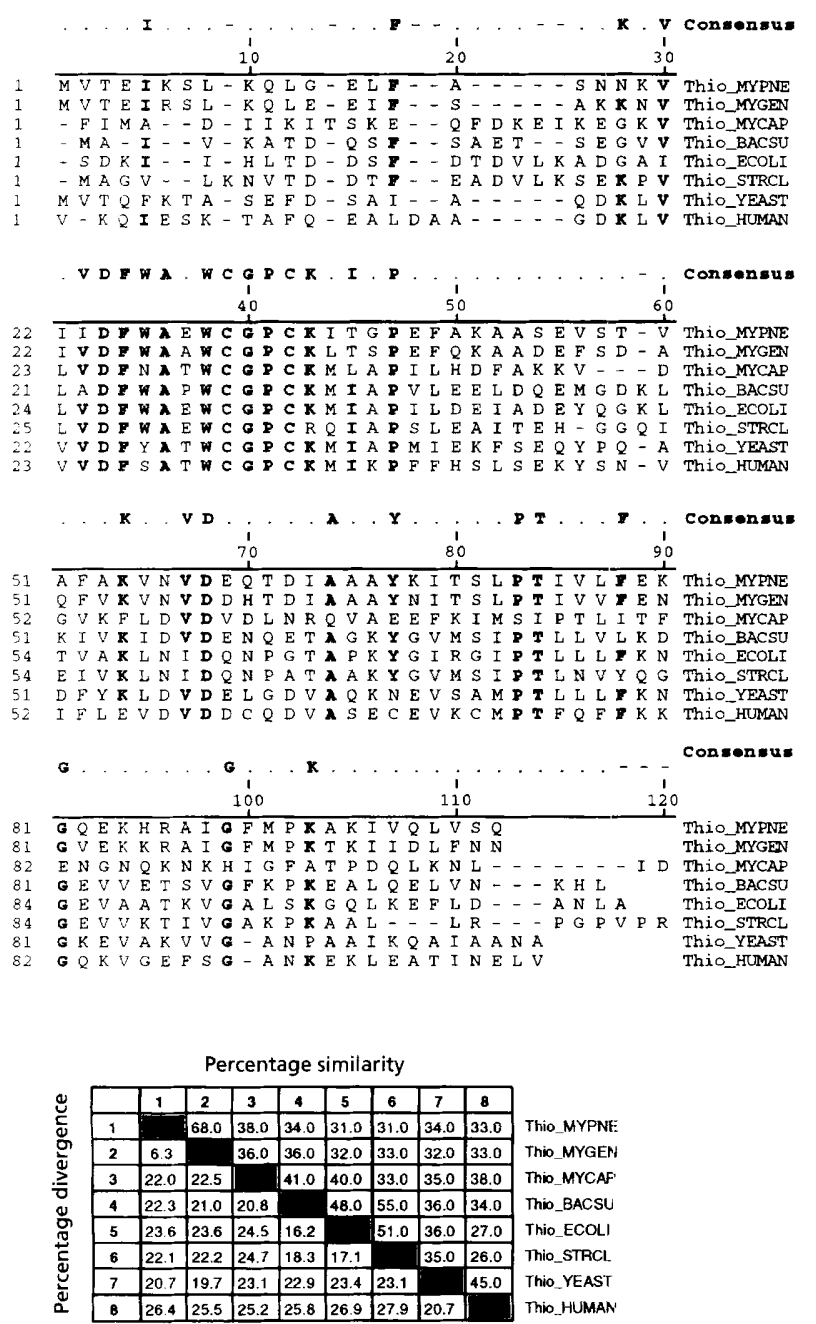

Fig. 5. Amino acid sequence alignment and homology comparison between TRX from selected organisms. MYPNE, $M$. pneumoniae (GenBank accession number U51987); MYGEN, $M$. genitalium (Fraser et al., 1995; L43967); MYCAP, M. capricolum (Bork et al., 1995; Z33053); BACSU, B. subtilis (Chen et al., 1989; P14949); ECOLI, E. coli (Lim et al., 1985; Russel \& Model, 1988; P00274); STRCL, Strep. clavuligerus (Cohen et al., 1993; Q05793); YEAST, Sacch. cerevisiae (Gan, 1991; P22217); HUMAN (Wollman et al., 1988; P10599). Consensus is the consensus sequence in which the same amino acid occurs in at least five of the sequences.

against E. coli did not (see Fig. 4). Moreover, an attempt to reconstitute the NTS system using $M$. pneumoniae NTR and various TRX preparations revealed that, similar to results obtained with $M$. capricolum NTR, activity was demonstrated only with the homologous (M. pneumoniae) TRX but not with M. capricolum, E. coli or B. subtilis TRX preparations (data not shown).

\section{Cloning and nucleotide sequence of the trxB gene}

Hybridization with the oligonucleotides o.THRSE1 and o.THRSE2 did not allow unambiguous identification of an EcoRI fragment in the cosmid library, or in digested

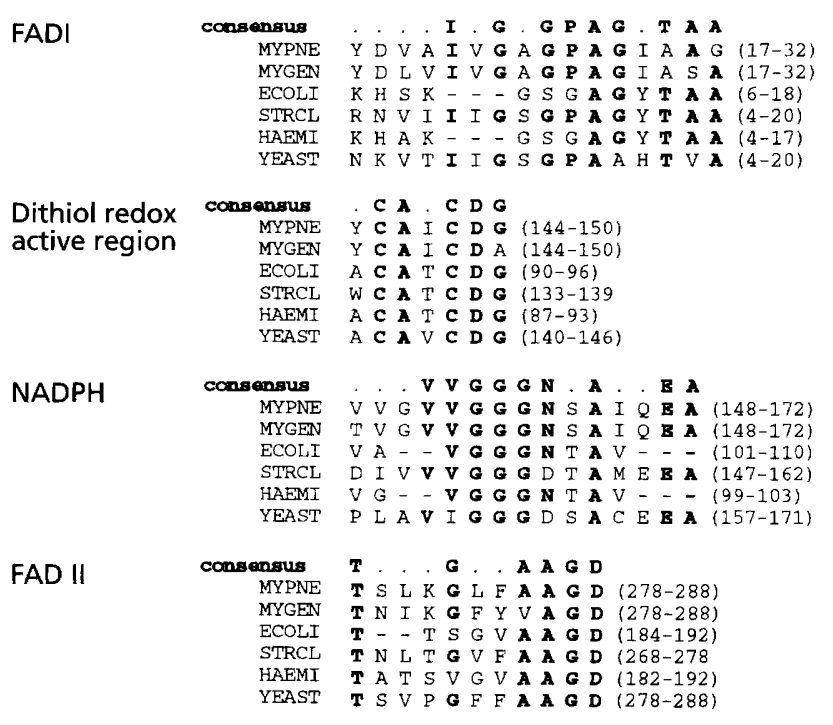

Fig. 6. Amino acid sequence alignment of dinucleotide-binding sites and dithiol redox-active region of NTR of selected bacteria. MYPNE, $M$. pneumoniae (NTR; GenBank accession number U51988); MYGEN, M. genitalium (Fraser et al., 1995); ECOLI, $E$. coli (Lim et al., 1985; Russel \& Nodel, 1988); STRCL, Strep. clavuligerus (Cohen et al., 1993); HAEMI, $H$. influenzae (Fleischmann et al., 1995); YEAST, Sacch. cerevisiae (Gan, 1991). Consensus is the consensus sequence in which the same amino acid occurs in at least four of the sequences.

genomic $M$. pneumoniae DNA. The negative results, multiple bands at low stringency and none at high stringency, strongly suggested that our probes were nonspecific. Repetition of the experiments with different sets of degenerate oligonucleotides was also unsuccessful. In the course of confirming the EcoRI restriction map of the $M$. pneumoniae genome, which was constructed on the basis of overlapping cosmid clones, we had to reexamine the overlap between the cosmids pcosMPK8, pcosMPK4 and pcosMPG7 (Wenzel \& Herrmann, 1989). To this end genomic M. pneumoniae DNA was amplified by PCR using oligonucleotides 0.3605 and 0.4257 as primers to yield a $6.8 \mathrm{kbp}$ fragment. Digestion of this fragment with the restriction endonuclease EcoRI produced 2.5 and $0.7 \mathrm{kbp}$ internal fragments and $0.14 \mathrm{kbp}$ and $3.8 \mathrm{kbp}$ end-fragments. The amplified internal PCR fragments were sequenced either directly or after cloning in bacteriophage M13. Nucleotide sequences derived from both DNA sources were in good agreement and permitted detection of an ORF encoding a protein of 315 aa with significant homology to bacterial NTRs. The FAD-binding domains I and II, the NADPH-binding domain and the cysteine dithiol redoxactive region were conserved (Fig. 6) except that the threonine at the active region of E. coli, H. influenzae and Strep. clavuligerus was replaced in M. pneumoniae by isoleucine. Since the corresponding DNA region was sequenced repeatedly, and since the NTR from $M$. genitalium shows the same modification, the sequence is probably correct. This suggests that a threonine in the third position of the active region is not essential. This 
notion is supported by the corresponding sequence of the NTR of Saccharomyces cerevisiae where the threonine is replaced by valine (Fig. 6). The sequence variation in the dithiol redox-active region of $M$. pneumoniae may explain the failure of oligonucleotides o.THRSE 1 and o.THRSE2 to bind as both were derived assuming the conserved amino acid sequence CATCDG.

\section{The possible role of NTS in mycoplasmas}

It has previously been shown that $M$. pneumoniae, as well as other pathogenic Mycoplasma species, produce reactive forms of oxygen such as hydrogen peroxide, superoxide radicals and hydroxy radicals (Lynch \& Cole, 1980; Tryon \& Baseman, 1992). It has been suggested that such reactive molecules cause injury to host cells by oxidizing membranes lipids as well as oxidizing host cell proteins, thus playing a major role in the pathogenesis of these organisms (Almagor et al., 1984). The complete nucleotide sequence of $M$. genitalium and M. pneumoniae genomes (Fraser et al., 1995; Himmelreich et al., 1996) show that these mycoplasmas appear to lack catalase, peroxidase or oxygen dismutases known to function in the removal of the deleterious hydrogen peroxide or oxygen radicals. Nonetheless, these organisms seem to be resistant to the effect of oxidative molecules (Tryon \& Baseman, 1992). It is likely that mycoplasmas have evolved other mechanisms to protect themselves from the consequences of their self-generated oxidative challenge. We suggest that the NTS described in the present study may function as a detoxifying system protecting mycoplasmas from reactive oxygen compounds. Such protection can be achieved either by direct catalysis of the reduction of protein disulfides and/or by maintaining intracellular pools of low molecular mass thiol metabolites in their reduced form.

\section{ACKNOWLEDGEMENTS}

We are grateful for the inspiration, encouragement and valuable advice of B. B. Buchanan. We thank A. Bosserhoff and R. Frank for the sequence analysis of the N-terminus of the thioredoxin from $M$. capricolum. This work was supported by a grant from the Ministerium für Wissenschaft und Kunst des Landes Baden-Wurtenberg.

\section{REFERENCES}

Aharonowitz, Y., Av-Gay, Y., Schreiber, R. \& Cohen, G. (1993). Characterization of a broad-range disulfide reductase from Streptomyces clavuligerus and its possible role in beta-lactam antibiotic biosynthesis. J Bacteriol 175, 623-629.

Almagor, M., Kahane, I. \& Yatziv, S. (1984). Role of superoxide anion in host cell injury induced by Mycoplasma pneumoniae infection: a study in normal and trisomy 21 cells. J Clin Invest 73, 842-847.

Ansorge, W., Sproat, B., Stegemann, J., Schwager, C. \& Zenke, M. (1987). Automated DNA sequencing: ultrasensitive detection of fluorescent bands during electrophoresis. Nucleic Acids Res 15, 4593-4602.

Ben-Menachem, G., Herrmann, R. \& Rottem, S. (1994). Thioredoxin and thioredoxin reductase in mollicutes. IOM Lett 3, 197.
Bork, P., Ouzounis, C., Casari, G., Schneider, R., Sander, C., Dolan, M., Gilbert, W. \& Gillevet, P. M. (1995). Exploring the Mycoplasma capricolum genome: a minimal cell reveals its physiology. Mol Microbiol 16, 955-967.

Bradford, M. M. (1976). A rapid and sensitive method for the quantitation of microgram quantities of protein utilizing the principle of protein-dye binding. Anal Biochem 72, 248-254.

Buchanan, B. B., Schurmann, P., Decottignies, P. \& Lozano, R. M. (1994). Thioredoxin: a multifunctional regulatory protein with a bright future in technology and medicine. Arch Biochem Biophys 314, 257-260.

Caruthers, M. H. (1982). New methods for synthesizing deoxyoligonucleotides. Genet Eng 4, 1-16.

Chen, N. Y., Zhang, J. J. \& Paulus, H. (1989). Chromosomal location of the Bacillus subtilis aspartokinase Il gene and nucleotide sequence of the adjacent genes homologous to $u v r C$ and trx of Escherichia coli. J Gen Microbiol 135, 2931-2940.

Cheng, S., Fockler, C., Barnes, W. M. \& Higuchei, R. (1994). Effective amplification of long targets from cloned inserts and human genomic DNA. Proc Natl Acad Sci USA 91, 5695-5699.

Cohen, G., Yanko, M., Mislovati, M., Argaman, A., Schreiber, R., Av-Gay, Y. \& Aharonowitz, Y. (1993). Thioredoxin-thioredoxin reductase system of Streptomyces clavuligerus: sequences, expression, and organization of the genes. J Bacteriol 175, 51595167.

Cohen, G., Argaman, A., Schreiber, R., Mislovati, M. \& Aharonowitz, Y. (1994). The thioredoxin system of Penicillium chrysogenum and its possible role in penicillin biosynthesis. J Bacteriol 176, 973-984.

Derman, A. I., Prinz, W. A., Belin, D. \& Beckwith, J. (1993). Mutations that allow disulfide bond formation in the cytoplasm of Escherichia coli. Science 262, 1744-1747.

Fernando, M. R., Nanri, H., Yoshitake, S., Nagata-Kuno, K. \& Minakami, S. (1992). Thioredoxin regenerates proteins inactivated by oxidative stress in endothelial cells. Eur J Biochem 209, 917-922.

Ferretti, L. S., Karnik, S., Khorana, H. G., Nassal, M. \& Oprian, D. D. (1986). Total synthesis of a gene for bovine rhodopsin. Proc Natl Acad Sci USA 83, 599-603.

Fleischmann, R. D. and others (1995). Whole-genome random sequencing and assembly of Haemophilus influenzae, Rd. Science 269, 496-512.

Fraser, C. M. and others (1995). The minimal gene complement of Mycoplasma genitalium. Science 270, 397-403.

Gan, Z. R. (1991). Yeast thioredoxin genes. I Biol Chem 266, 2736-2742.

Gleason, F. K. \& Holmgren, A. (1988). Thioredoxin and related proteins in procaryotes. FEMS Microbiol Rev 54, 271-298.

Himmelreich, R., Hilbert, H., Plagens, H., Pirkl, E., Li, B. C. \& Herrmann, R. (1996). Complete sequence analysis of the genome of the bacterium Mycoplasma pneumoniae. Nucleic Acids Res 24, 4420-4449.

Holmgren, A. (1977). Bovine thioredoxin system: purification of thioredoxin reductase from calf liver and thymus and studies of its function in disulfide reduction. J Biol Chem 252, 4600-4606.

Holmgren, A. (1979a). Reduction of disulfides by thioredoxin. Exceptional reactivity of insulin and suggested functions of thioredoxin in mechanisms of hormone action. J Biol Chem 254, 9113-9119.

Holmgren, A. (1979b). Thioredoxin catalyzes the reduction of 
insulin disulfides by dithiothreitol and dihydrolipoamide. $J$ Biol Chem 254, 9627-9632.

Laemmli, U. K. (1970). Cleavage of structural proteins during the assembly of the head of bacteriophage T4. Nature 227, 680-685.

Lim, C.-J., Geraghty, D. \& Fuchs, J. A. (1985). Cloning and nucleotide sequence of the trxA gene of Escherichia coli K12.J Bacteriol 163, 311-316.

Luthman, M. \& Holmgren, A. (1982). Rat liver thioredoxin and thioredoxin reductase: purification and characterization. Biochemistry 21, 6628-6633.

Lynch, R. E. \& Cole, B. C. (1980). Mycoplasma pneumoniae: a pathogen which manufactures superoxide but lacks superoxide dismutase. Proc FEBS Symp 62, 49-56.

Matthews, J. R., Wakasugi, N., Virelizier, J. L., Yodoi, J. \& Hay, R. T. (1992). Thioredoxin regulates the DNA binding activity of NFkappa B by reduction of a disulphide bond involving cysteine 62 . Nucleic Acids Res 20, 3821-3830.

Pigiet, V.P. \& Schuster, B. J. (1986). Thioredoxin-catalyzed refolding of disulfide-containing proteins. Proc Natl Acad Sci USA 83, 7634-7647.

Razin, S. \& Rottem, S. (1976). Mycoplasma membranes. In Biochemical Analysis of Membranes, pp. 3-26. Edited by A. M. Maddy. London: Chapman and Hall.

Russel, M. \& Model, P. (1988). Sequence of thioredoxin reductase from Escherichia coli. Relationship to other flavoprotein disulfide oxidoreductases. J Biol Chem 263, 9015-9019.

Sambrook, J., Fritsch, E. F. \& Maniatis, T. (1989). Molecular Cloning: a Laboratory Manual. Cold Spring Harbor, NY: Cold Spring Harbour Laboratory.
Sanger, F., Nicklen, S. \& Coulson, A. R. (1977). DNA sequencing with chain-terminating inhibitors. Proc Natl Acad Sci USA 79 5463-5467.

Schenk, H., Klein, M., Erdbrugger, W., Droge, W. \& Schulze, O. K. (1994). Distinct effects of thioredoxin and antioxidants on the activation of transcription factors NF-kappa B and AP-1. Proc Natl Acad Sci USA 91, 1672-1676.

Shirazi, I., Tarshis, M. \& Rottem, S. (1995). An arginine-ornithine exchange system in Spiroplasma melliferum cells. Microbiology $141,2323-2328$.

Tryon, V. V. \& Baseman, J. B. (1992). Pathogenic determinants and mechanisms. In Mycoplasmas: Molecular Biology and Pathogenesis, pp. 457-471. Edited by J. Maniloff, R. N. McElhaney, L. R. Finch \& J. B. Baseman. Washington, DC: American Society for Microbiology.

Wenzel, R. \& Herrmann, R. (1988). Physical mapping of the Mycoplasma pneumoniae genome. Nucleic Acids Res 16, 8323 8336.

Wenzel, R. \& Herrmann, R. (1989). Cloning of the complete Mycoplasma pneumoniae genome. Nucleic Acids Res 17, 7029 7043.

Wollman, E. E., D'Auriol, L., Rimsky, L., Shaw, A., Jacquot, J., Wingfield, P. P., Graber, P. \& Dessarps, F. (1988). Cloning and expression of a cDNA from human thioredoxin. J Biol Chem 263, 15506-15512.

Wong, J. H., Kobrhel, K. \& Buchanan, B. B. (1995). Thioredoxin and seed proteins. Methods Enzymol 252, 228-240.

Received 5 September 1996; revised 31 December 1996; accepted 20 January 1997. 